\title{
Vakuum sušenje u prehrambenoj industriji
}

\author{
Vacuum drying in Food Industry
}

\author{
Marko Marelja, Filip Dujmić, Damir Ježek, Marko Škegro, Tomislav Bosiljkov, Sven Karlović, Monika Lasić, \\ Mladen Brnčić*
}

Prehrambeno-biotehnološki fakultet; Sveučilište u Zagrebu; Pierottijeva 6; Zagreb

*Corresponding author: mbrncic@pbf.hr

\begin{abstract}
Sažetak
Sušenje je jedan od najstarijih i najekonomičnijih procesa produljenja trajnosti hrane. Osušeni proizvodi imaju manju masu $i$ volumen što olakšava $i$ smanjuje troškove pakiranja, skladištenja i transporta. Nedostatci prilikom konvencionalnog sušenja prehrambenih sirovina su toplinska razgradnja nutritivno vrijednih sastojaka, boje, mogući gubitci arome, nepoželjne promjene oblika i teksturalnih svojstava te enzimsko posmeđivanje. Ti nedostatci se mogu značajno smanjiti sušenjem u vakuumu. Konvencionalno vakuum sušenje i mikrovalno vakuum sušenje te sušenje zamrzavanjem u vakuuтu su najpoznatiji procesi sušenja u vakuumu. Prednosti sušenja u vakuumu su niže temperature sušenja što rezultira većim očuvanjem hranjivih tvari proizvoda odnosno boljom kvalitetom sušenog proizvoda.
\end{abstract}

Ključne rječi: vakuum sušenje, mikrovalovi, liofilizacija, potrošnja energije, nutritivna vrijednost

\begin{abstract}
Drying is one of the oldest and most cost-effective ways of preserving foods used to prolong the shelf life of food. The reduced volume and moisture of the dried product facilitates and minimizes packaging, storage and transportation costs. Disadvantages in conventional drying of food are heat degradation of nutrient ingredients, color, possible flavor loss, undesirable shapes and texture alterations, enzymatic browning. These shortcomings can be significantly reduced by drying at reduced pressure. Conventional vacuum drying, microwave-vacuum drying, and freeze-drying processes are the most known vacuum drying processes. The benefits of vacuum drying are lower drying temperatures and consequently higher preservation of nutrients resulting in a better product quality.
\end{abstract}

Key words: vacuum drying, microwaves, freeze drying, energy consumption, nutritive value

\section{Uvod}

Najstariji način konzerviranja hrane je sušenje korištenjem sunčeve energije. Uklanjanjem vode iz hrane smanjuje se rast mikroorganizama i enzimska aktivnost što proces sušenja i u današnje vrijeme svrstava u jedan od najvažnijih tehnoloških postupaka. Sušenjem se dio vode iz čvrste tvari uklanja ishlapljivanjem čime se smanjuje vlažnost površine tvari i radi nastale razlike koncentracije voda difundira iz unutrašnjosti prema površini tvari. Brzina ishlapljivanja vode s površine tvari ovisi o brzini gibanja zraka oko materijala i vrsti veze između materijala i vode. Kako bi uklonili vodu potrebno je poznavati kemijski sastav i fizikalnu strukturu svježe namirnice. U hrani voda može biti prisutna kao slobodna i vezana voda. Slobodna voda je voda koja je vezana slabim vezama na pojedine sastojke hrane, voda koja se nalazi u gelovima,voda prisutna kao kontinuirana faza u kojoj su druge tvari otopljene,suspendirane, dispergirane molekularno, koloidno ili kao emulzija te voda kao čista komponenta koja se nalazi na površini hrane koja nije dio proizvoda već dolazi izvana.Vezana voda je voda koja se nalazi u hrani kao voda koja je čvrsto vezana vodikovim vezama na polarne sastojke hrane (proteini, ugljikohidrati) i voda koja je kemijski vezana na nekim solima primarnom valencijom ili kao hidrat te voda koja se nalazi u kapilarnim prostorima. Sušenje je kompleksan fizikalni proces koji istovremeno uključuje prijenos mase i energije (topline), a brzina sušenja nije u svim fazama procesa jednaka. Proces sušenja u struji zraka kod konstantne temperature i vlažnosti dijeli se na period konstantne brzine i jedan ili više perioda padajuće brzine sušenja ovisno o higroskopičnosti materijala koji se suši. U periodu konstantne brzine sušenja količina vode na površini materijala je takva da je parcijalni tlak vode na površini hrane jednak parcijalnom tlaku zasićenja temperature mokrog termometra. Period konstantne brzine sušenja traje dok se vode na površini nadoknađuje kapilarnim tokom kojim se održava konstantna temperatura. Prvi period padajuće brzine sušenja u unutrašnjosti materijala završava kada u unutrašnjosti materijala ne vladaju uvjeti zasićenja. Drugi period padajuće brzine sušenja odvija se kod higroskopičnih materijala, a završava kada u središnjem dijelu materijala nema više dovoljno vode da se održava parcijalni tlak, a sadržaj vlage jednak je kritičnom sadržaju vlage. Postupkom sušenja treba upravljati tako da se osigura kontinuirana difuzija vode iz unutrašnjosti prema površini materijala. Ukoliko se postupak sušenja vodi na neodgovarajući način, dolazi do površinski neujednačenog pregrijavanja uzorka, što sprječava optimalnu difuziju vode prema površini materijala. Neujednačenom difuzijom vode dolazi do stvaranja pokorice na površini materijala, što otežava sušenje te za posljedicu može imati nedovoljno sušen proizvod, narušenih senzorskih i fizikalno-kemijskih svojstava. U svrhu sprječavanja mikrobiološkog kvarenja hrane, poželjno je da vlažnost materijala ne prelazi $10 \%$ (Zambrano i sur., 2019). Odabir procesa sušenja i opreme ovise o 
brojnim čimbenicima budući da se razlikuju po načinu prijenosa topline, energetskoj učinkovitosti, trajanju sušenja, ali i vrsti, sastavu i fizikalnim svojstvima proizvoda te željenim svojstvima konačnog proizvoda (nutritivna, organoleptička i rehidratacijska svojstva) (Berk, 2009). Od ključne je važnosti postići ravnotežu svih navedenih čimbenika kako bi se proizveo ekonomski isplativ proizvod te zadovoljili tehnološki, sigurnosni i potrošački zahtjevi. Radi velikog utroška energije moguće degradacije visokovrijednih sastojaka hrane sušenje predstavlja operaciju koju treba pažljivo voditi i kontrolirati (van’t Land, 2011a). Kod određenih materijala potrebno je provesti pripremu i predobradu prije sušenja (na primjer: za voće i povrće: sortiranje i klasiranje prema veličini, boji, stupnju zrelosti, pranje, guljenje, rezanje i usitnjavanje, blanširanje; za meso: rezanje, uklanjanje suviška masnog tkiva, kuhanje, dodatak antioksidansa; za tekuću hranu kao što su mlijeko i jaja: pasterizacija, sterilizacija, dodatak antioksidansa i tvari za rahljenje). Stoga, glavni tehnološki ciljevi sušenja hrane su očuvanje nutritivnog sadržaja smanjenjem aktivnosti vode te smanjenje mase i volumena, čime je proizvod pogodniji za skladištenje, pakiranje, transport i uporabu. U ovom preglednom radu opisani su različiti procesi vakuum sušenja. Svaki proces sušenja ima određene prednosti i nedostatke, a vakuum sušenje se najčešće koristi za materijale koji bi mogli značajno promijeniti svojstva ako ih se izloži visokim temperaturama odnosno za materijale sklone oksidaciji.

\section{Vakuum sušenje}

Vakuum sušenje se odvija pri sniženim tlakovima i sniženoj temperaturi vrelišta vode što pridonosi očuvanju toplinski osjetljivih nutritivnih sastojaka i senzorskih svojstava hrane, posebno boje. Sušenje pri subatmosferskim tlakovima ima višestruke prednosti prilikom sušenja toplinski osjetljivih materijala kod kojih bi se toplinski nestabilne tvari sušenjem pri atmosferskom tlaku i višim temperaturama sušenja razgradile, a ako bi se proces odvijao pri nižim temperaturama, onda bi proces sušenja trajao dulje. Također, prilikom vakuum sušenja, smanjena je volumna koncentracija kisika, čime se osigurava bolja oksidacijska stabilnost sušenog materijala (Arevalo-Pinedo i sur., 2006). Nadalje, proizvodi osušeni u vakuumu brže se i bolje rehidratiraju zbog poroznije strukture. Nedostaci vakuum sušenja uključuju veće inicijalne i operativne troškove budući da su uređaji zbog složene izvedbe skupi. Pored toga, nužno je održavanje sniženog tlaka u vakuum komori, a upravljanje procesom je složeno. Proces se uglavnom odvija u šaržama. Ograničenje vakuum sušenja je povezano s načinom prijenosa topline. Prijenos topline $\mathrm{u}$ vakuum sušari provodi se uglavnom radijacijom topline infacrvenim grijačima i kondukcijom gdje se toplina dovodi kroz zagrijanu plohu te je sušenje ograničeno površinom dostupnom za prijenos topline, a rjeđe konvekcijom gdje se vlažna tvar zagrijava strujom vrućeg zraka ili inertnog plina. Temperature sušenja koje se najčešće koriste pri vakuum sušenju prehrambenih sirovina te odgovarajući tlakovi koje je nužno postići da bi se postigla temperatura vrelišta vode su prikazane u Tablici 1.

Tablica 1. Apsolutni tlakovi pri kojima se postiže vrelište vode u hrani pri različitim temperaturama sušenja (Koretsky, 2004)

Table 1. Absolute pressure for boiling the water in the food at different drying temperatures (Koretsky, 2004)

\begin{tabular}{|c|c|}
\hline Vrelište vode $\left({ }^{\circ} \mathrm{C}\right)$ & Apsolutni tlak (kPa) \\
\hline 30 & 4,246 \\
\hline 40 & 7,384 \\
\hline 50 & 12,350 \\
\hline 60 & 19,941 \\
\hline 70 & 31,188 \\
\hline 80 & 47,390 \\
\hline
\end{tabular}

\section{Konvencionalno vakuum sušenje}

Kod konvencionalnog vakuum sušenja koriste se izvedbe industrijskih vakuum sušara kod kojih se toplina na materijal prenosi kondukcijom, konvekcijom ili radijacijom infra-crvenih elektromagnetskih valova. Konvencionalno vakuum sušenje provodi se pri nižim temperaturama u odnosu na konvencionalno sušenje vrućim zrakom. Uvjeti sušenja za različite vrste prehrambenih sirovina pri konvencionalnom vakuum sušenju prikazani su u Tablici 2.

Tablica 2. Uvjeti pri konvencionalnom vakuum sušenju za različite vrste sirovina

Table 2. Vacuum drying conditions of foods

\begin{tabular}{|c|c|c|c|c|}
\hline Sirovina & Temperatura $\left({ }^{\circ} \mathrm{C}\right)$ & Tlak $(\mathrm{kPa})$ & Debljina uzorka $(\mathrm{mm})$ & Literaturni navod \\
\hline celer & $65-75$ & $2,13-2,67$ & $1-3$ & Madamba i Liboon, 2007 \\
\hline mango & $65-75$ & $4,00-6,67$ & $2-4$ & Jaya i Das, 2003 \\
\hline pogača kokosa & $65-75$ & 8,26 & $2-4$ & Jena i Das, 2007 \\
\hline patlidžan & $30-50$ & $2,5-10$ & - & Wu i sur., 2007 \\
\hline crveni luk & $50-70$ & 6,67 & $1-5$ & Mitra i sur, 2011 \\
\hline mljeveno meso & $25-45$ & 8 & 5 & da Silva i sur., 2018 \\
\hline papaja & 60 & 30 & 4 & Orikasa i sur., 2014 \\
\hline kivi & $50-70$ & 3 & 10 & Arevalo Pinedo i Murr, 2006 \\
\hline bundeva & $50-70$ & $5-25$ & 5 & Balzarini i sur., 2018 \\
\hline cikorija & 60 & 3,33 & 10 & Liu i sur., 2018 \\
\hline krumpir & $40-70$ & 30 & 2,5 & Tekin i sur., 2017 \\
\hline mahuna & $55-75$ & 8 & 7 & Sic Žlabur i sur., 2019 \\
\hline sibirska borovnica & $40-60$ & 6,67 & $500 \mathrm{~g}$ & Šumić i sur., 2017 \\
\hline gljive lisičarke & $46-74$ & $2-58$ & $370 \mathrm{~g}$ & \\
\hline
\end{tabular}


Najčešće izvedbe industrijskih vakuum sušara su pločaste, trakaste i mješajuće (Reis i sur., 2014).

Pločasta vakuum sušara je kontaktna sušara jednostavne izvedbe, bez pomičnih dijelova (Slika 1). Šaržno punjenje ih čini nepraktičnim za kontinuiranu proizvodnju. U komori iz koje se ispumpa željena količina zraka, smješten je niz polica na koje se slaže materijal za sušenje. Ploče se griju cirkulacijom vruće vode ili pare, a toplina se na materijal u najvećoj mjeri prenosi kondukcijom. Para nastala sušenjem apsorbira se vakuum pumpom, a stopa jednosatnog isparavanja ovog tipa sušare relativno je niska i varira između 0,1 i $0,2 \mathrm{~kg}$ vlage po kvadratnom metru grijače ploče (van’t Land, 2011c). Najviše temperature ploča kreću se oko $150{ }^{\circ} \mathrm{C}$. Pločaste vakuum sušare često se koriste za materijale koji lako oksidiraju i zahtijevaju niske temperature sušenja. Industrijski modeli raspoloživi su u dimenzijama do nekoliko kubnih metara.

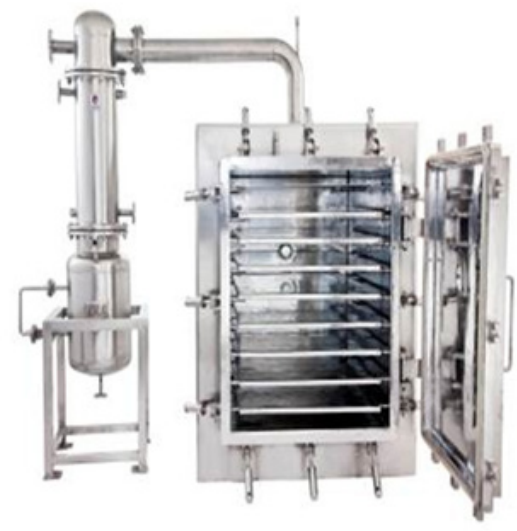

Slika 1. Pločasta vakuum sušara (Anonymus 1) Figure 1. Vacuum tray dryer (Anonymus 1)

Arevalo-Pinedo i suradnici (2010) su u pločastoj vakuumskoj sušari pri različitim temperaturama $\left(50,60\right.$ i $\left.70{ }^{\circ} \mathrm{C}\right)$ u uvjetima niskog tlaka $(5$, 15 i $25 \mathrm{kPa}$ ) sušili uzorke svježe i zamrznute mrkve narezane na kriške. Najbolja difuznost vlage ostvarena je pri najvišoj temperaturi i najnižem tlaku u zamrznutim uzorcima. Glavni čimbenici koji su utjecali na kinetiku sušenja kriški mrkve bili su predobrada zamrzavanjem i tlak u komori za sušenje. Rezultati istraživanja Šic Žlabur i suradnika (2019) su pokazali da se predobradom ultrazvukom i sušenjem borovnica u pločastoj vakuum sušari dobivaju kvalitetniji proizvodi u odnosu na kondukcijsko sušenje. U borovnicama sušenim u vakuumu očuvana je veća količina vitamina $\mathrm{C}$, ukupnih fenola i antocijana.

Kontinuirana trakasta vakuum sušara sastoji se od vakuum komore, u kojoj je smještena jedna ili više prijenosnih traka koje prelaze preko zagrijanih ploča ili ispod infracrvenih grijača (Slika 2). Za stvaranje vakuuma u sušari koristi se različite izvedbe vakuum pumpi (difuzijske i/ili prstenaste pumpe). Kod sušenja pasta i tekućina, koriste se oscilirajuće ili fiksne mlaznice za kontinuiranu distribuciju proizvoda na pokretne trake koje se gibaju u jednom smjeru. Čestice se pune samo na gornjoj traci i sve su trake usmjerene naizmjenično u suprotnim smjerovima, tako da na krajnjem području gornje trake proizvod pada na sljedeću niže smještenu traku gdje se sušenje nastavlja. Materijal se transportira naizmjeničnim smjerovima kroz sušaru sve dok se ne isprazni sa najniže trake. Temperatura ploča ispod druge trake može biti različita od temperature ispod prve trake, a u rasponu su od 20 do $165{ }^{\circ} \mathrm{C}$ pri tlaku od 10 do 100 mbara. Stopa isparavanja je uglavnom od 0,5 do $2 \mathrm{~kg} / \mathrm{m}^{2} \mathrm{~h}$, a vrijeme zadržavanja 15 do 75 minuta. Ploče najniže trake mogu se ohladiti da proizvod pri izlasku iz sušare ne veže vlagu iz zraka (van't Land, 2011c). Svaka traka prolazi preko niza ploča obično grijanih parom ili vrućom vodom koje su na različitoj temperaturi, kako bi se mogao kvalitetno kontrolirati proces sušenja i hlađenja. Kako proizvod prolazi kroz sušaru, vlaga iz materijala isparava. Ohlađeni kolač se odvaja na valjcima za lomljenje te pada preko izlazne drobilice. Kontinuirane trakaste vakuum sušare najčešće se koriste za dobivanje praškastih prehrambenih (instant proizvodi, dehidrirani voćni sokovi, praškasti napitci, mješavine za juhe) i farmaceutskih proizvoda (biljni ekstrakti) (van’t Land, 2011c).

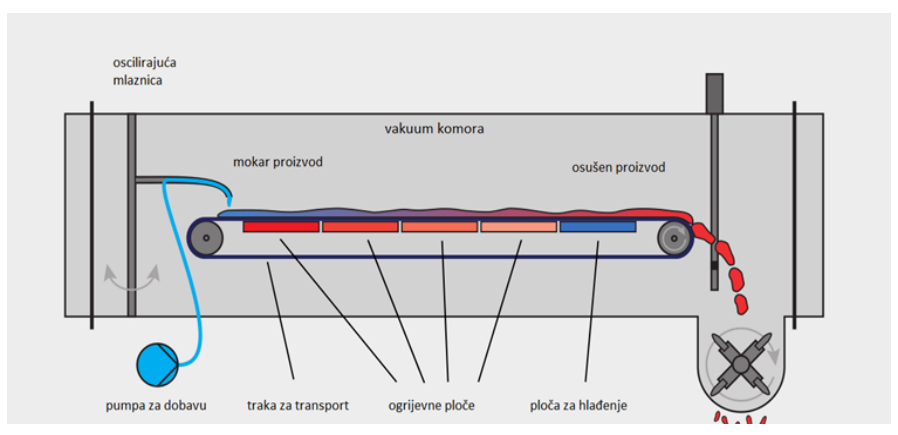

Slika 2. Kontinuirana trakasta vakuum sušara (Anonymus 2) Figure 2. Continuous belt vacuum dryer (Anonymus 2)

Yan i Kerr (2012) istražili su utjecaj sušenja u kontinuiranoj tračnoj infracrvenoj vakuum sušari pod apsolutnim tlakom od $2,9 \mathrm{kPa}$ i pri različitim temperaturama $\left(80{ }^{\circ} \mathrm{C}, 95{ }^{\circ} \mathrm{C}\right.$ i $\left.110{ }^{\circ} \mathrm{C}\right)$ na kvalitetu komine jabuke te usporedili sa sušenjem zamrzavanjem. Vrijeme sušenja trajalo je 96 minuta pri $110{ }^{\circ} \mathrm{C}, 130$ minuta pri $95{ }^{\circ} \mathrm{C}$ i 170 minuta pri $80{ }^{\circ} \mathrm{C}$. Određivali su boju i kemijski sastav uzoraka uključujući ukupan sadržaj fenola, monomernih antocijana i prehrambenih vlakana. Sušenjem u kontinuiranoj trakastoj infracrvenoj vakuum sušari svi prahovi komine jabuka imali su svjetlo zlatno-žutu boju, a prahovi sušeni pri temperaturi od $80{ }^{\circ} \mathrm{C}$ su bili najsvjetlije boje sa najvećim udjelom fenolnih spojeva dok uvjeti sušenja nisu utjecali na ukupni udio prehrambenih vlakana (442 do $495 \mathrm{~g} / \mathrm{kg}$ ). Nisu utvrđene značajne razlike u boji i udjelu ukupnih fenola kod komine osušene zamrzavanjem u odnosu na kominu osušenu u kontinuiranoj tračnoj infracrvenoj vakuum sušari.

Mješajuće vakuum sušare dolaze u dvije glavne vrste izvedbi: rotacijske i s mješalicama (Slika 3).

a)

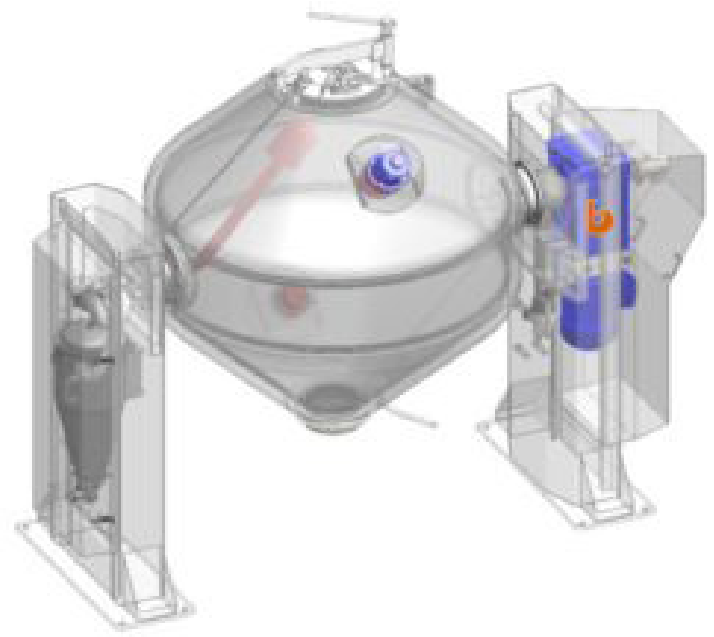


b)

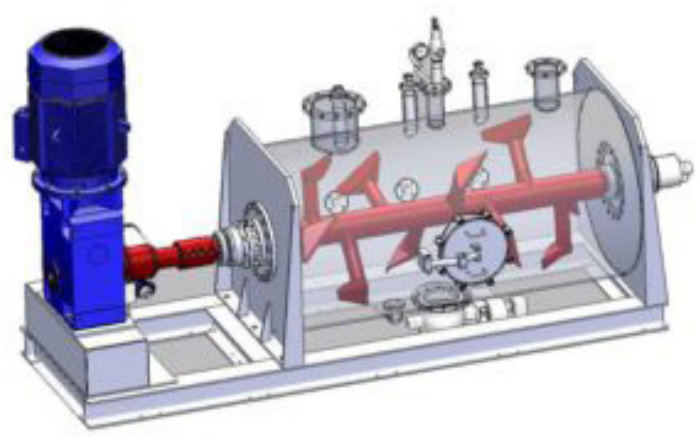

Slika 3. Mješajuće vakuum sušare: a) rotacijska i b) s mješalicama (Anonymus 3)

Figure 3. Mixing vacuum dryer: a) rotational and b) paddle dryer (Anonymus 3)

Rotacijske stožaste vakuum sušare najčešće se koriste u farmaceutskoj industriji te u proizvodnji aditiva, aroma i vitamina pri brzinama 30 do 60 okretaja u minuti.

Vakuum sušare s mješalicama se najčešće koriste za sušenje proizvoda velike viskoznosti (aditivi, ekstrakti, bojila, proteini). Ciklusi sušenja traju do 20 sati pri brzini rotacije 5 do 30 okretaja u minuti.

\section{Sušenje zamrzavanjem u vakuumu (liofilizacija)}

Sušenje zamrzavanjem u vakuumu (liofilizacija) je proces koji se najčešće koristi u farmaceutskoj i prehrambenoj industriji za sušenje proizvoda velike vrijednosti, a koji su termolabilni i podložni hidrolizi (Ratti, 2001). Liofilizacija omogućava uklanjanje vode iz osjetljivog prehrambenog materijala koji se primjenom uobičajenih postupaka sušenja ne može sušiti ili se suši nedovoljno. Liofilizacija se naziva novom tehnologijom prerade hrane 21. stoljeća. Trenutno, na međunarodnom tržištu, cijena liofilizirane hrane je 7 do 8 puta viša u odnosu na brzo zamrznutu hranu, a 4 do 6 puta u odnosu na hranu sušenu konvencionalnim procesom sušenja (Hua i sur., 2018). S druge strane, liofilizacija je energetski zahtjevniji i dugotrajniji proces $\mathrm{u}$ odnosu na ostale procese sušenja te su inicijalni troškovi nabave opreme veći. Ovaj način sušenja ima svoje ekonomsko opravdanje kod sušenja proizvoda vrhunske kvalitete i velike tržišne vrijednosti. Za proizvodnju liofiliziranog proizvoda vrhunske kvalitete nužno je dobro optimirati parametre prijenosa topline i mase koji imaju odlučujući utjecaj na kvalitetu sušenog proizvoda, ali i poznavati koligativna svojstva sirovine. Temelji se na dehidraciji sublimacijom zamrznutog proizvoda, a sam proces se sastoji od više faza:

1. prijelaz vode u čvrsto stanje zamrzavanjem gdje posebnu pozornost treba obratiti na konačnu temperaturu koja treba biti niža od eutektičke temperature i temperature staklastog prijelaza te brzinu snižavanja temperature. Zamrzavanje se najčešće provodi pri temperaturi nižoj od $-40{ }^{\circ} \mathrm{C}$. Brzina zamrzavanja ima značajan utjecaj na morfološka svojstva (strukturu i konzistenciju), boju i zadržavanje arome liofilizata. Brzina zamrzavanja utječe na veličinu kristala leda. Naime, što je zamrzavanje brže, kristali leda su manji, a njihova ukupna površina veća, kao i poroznost liofilizata. Dakle, o uspješnosti provođenja ove faze liofilizacije ovisit će i učinkovitost sušenja. Naime, veličina kristala leda, definirana u fazi zamrzavanja, određuje brzinu sublimacije. Što su kristali leda manji i specifična površina veća, sublimacija će biti brža. Brzina zamrzavanja za prehrambene proizvode se najčešće izražava $\mathrm{u} \mathrm{cm} / \mathrm{h}$ i kreće se u rasponu 0,3 do 3 , a za farmaceutske proizvode $\mathrm{u}$ ${ }^{\circ} \mathrm{C} / \mathrm{min}$ i kreće se u rasponu od 3 do 25 . Postupak zamrzavanja odvija se pri atmosferskom tlaku.

2. sublimacija - primarno sušenje se odvija pod vakumom pri kojem se sva slobodna voda u obliku leda sublimira u vodenu paru pri uvjetima sniženog tlaka i temperature. Pri sublimaciji leda u namirnicama ostaje određena količina vezane vode koja ne sublimira. Primarno sušenje je najduža faza procesa liofilizacije.

3. desorpcija - sekundarno sušenje pri kojem se desorbira vezana voda pri sobnoj ili povišenim temperaturama pod visokim vakumom, dok se ne dobije produkt $\mathrm{s}$ prihvatljivim sadržajem ostatne vlage, uglavnom nižim od $5 \%$. Sekundarno sušenje traje kraće od primarnog sušenja. Za farmaceutske proizvode desorpcija se provodi pri temperaturama do 40 ${ }^{\circ} \mathrm{C}$, dok za prehrambene sirovine može biti i do $70{ }^{\circ} \mathrm{C}$.

Primarno sušenje predstavlja kritičan korak liofilizacije. Nužno je dobro optimirati prijenos mase i prijenos topline kako ne bi došlo do neželjenih promjena zamrznutog uzorka prekomjernim dovođenjem topline, npr. taljenja, ekspanzije ili urušavanja. Uvjeti pri kojima se najčešće provodi liofilizacija su površinska temperatura proizvoda između 35 i $80{ }^{\circ} \mathrm{C}$ i tlaka od 13 do $270 \mathrm{~Pa}$ (Reis, 2014). Ako bi se, na primjer, željelo provesti sublimaciju leda pri $-40{ }^{\circ} \mathrm{C}$, tlak u komori za sušenje mora biti $12,9 \mathrm{~Pa}$ (Tablica 3).

Tablica 3. Temperature i tlakovi pri sublimaciji leda (Hua i suradnici, 2018)

Table 3. The saturated pressure of ice with temperature (Hua et al., 2018)

\begin{tabular}{|c|c|c|c|c|c|c|c|c|}
\hline Temperatura $\left({ }^{\circ} \mathrm{C}\right)$ & -70 & -60 & -50 & -40 & -30 & -20 & -10 & 0,01 \\
\hline Tlak $(\mathrm{Pa})$ & 0,262 & 1,11 & 3,94 & 12,9 & 38,0 & 103,3 & 259,9 & 610,62 \\
\hline
\end{tabular}

Sušenje zamrzavanjem u vakuumu provodi se u liofilizatoru koji se sastoji od tri osnovne komponente, a to su komora za sušenje s policama, vakuumska pumpa koja osigurava niski tlak u komori za sušenje i kondenzator koji sakuplja vlagu kondenzacijom na hladnoj površini (Slika 4.). Ambalaža, uvjeti pakiranja i skladištenja su važni parametri održavanja kvalitete liofiliziranog proizvoda koji su osjetljivi na vlagu, kisik i svjetlo zbog čega se najčešće pakiraju u kontroliranoj atmosferi (suhi inertni plin) u odgovarajuću ambalažu (plastične folije, laminate) te skladište na sobnoj temperaturi.

Liofilizacijom prehrambenih sirovina dobiva se hrana dodane vrijednosti dulje trajnosti, bolje boje, mirisa i okusa, s manjim gubicima bioaktivnih tvari (Tablica 4). Tako osušena hrana ima poroznu strukturu, dobru topljivost ako je u obliku prahu i lako se rehidrira. 


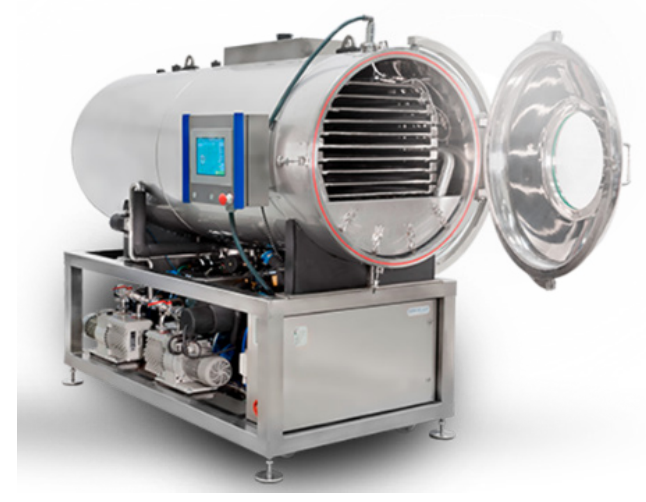

Slika 4. Liofilizator (Anonymus 4)

Figure 4. Lyophilizer (Anonymus 4)

Tablica 4. Udio ukupnih fenola u voću i povrću kod sušenja u struji vrućeg zraka i sušenja zamrzavanjem u vakuumu (liofilizacija)

Table 4. Total phenols content of hot-air and freeze-dried fruit and vegetables

\begin{tabular}{|c|c|c|c|c|c|}
\hline Sirovina & $\begin{array}{c}\text { HAD } \\
\text { Temperatura } \\
\left({ }^{\circ} \mathrm{C}\right)\end{array}$ & $\begin{array}{c}\text { FD } \\
\text { Temperatura }\left({ }^{\circ} \mathrm{C}\right) \mathrm{i} \text { tlak } \\
(\mathrm{Pa})\end{array}$ & $\begin{array}{c}\text { HAD } \\
\text { Udio ukupnih fenola } \\
(\mathrm{GAE} / 100 \mathrm{~g})\end{array}$ & $\begin{array}{c}\text { FD } \\
\text { Udio ukupnih fenola } \\
(\mathrm{GAE} / 100 \mathrm{~g})\end{array}$ & Literaturni navod \\
\hline kivi & 60 & $-50 ; 10,0$ & 721 & 962 & Akar i Mazi, 2019 \\
\hline kupus & 55 & $-40 ;-$ & 905 & 1132 & Korus, 2011 \\
\hline rajčica & 60 & $-50 ; 13,3$ & 346 & 654 & Gümüşay i sur., 2014 \\
\hline đumbir & 60 & $-50 ; 13,3$ & 354 & 910 & Gümüşay i sur., 2014 \\
\hline
\end{tabular}

HAD - sušenje u struji vrućeg zraka

FD - sušenje zamrzavanjem u vakuumu (liofilizacija)

Sramek i suradnici (2015) usporedili su utjecaj liofilizacije $(0,85$ mbar, $\left.-45^{\circ} \mathrm{C}\right)$, konvekcijskog sušenja vrućim zrakom $(50,60$ i 70 $\left.{ }^{\circ} \mathrm{C}\right)$ i kondukcijskim sušenjem pod vakuumom prethodno upjenjenog materijala iz dvostruko koncentrirane paste od rajčice na boju i udio likopena i $\beta$-karotena. Kondukcijsko sušenje pod vakuumom provodilo se pri temperaturama od $50,60 \mathrm{i} 70{ }^{\circ} \mathrm{C}$ i tlaku od 200 mbar do konačnog udjela vlage od 5,6 do 7,5\%. Najmanja promjena boje utvrđena je kod uzoraka sušenih u vakuumu, a najveća kod uzoraka sušenih konvekcijski vrućim zrakom. Najveći udio likopena i i $\beta$-karotena imali su uzorci osušeni kondukcijski pod vakuumom pri temperaturama od $50{ }^{\circ} \mathrm{C}$. Rezultati ovog istraživanja ukazuju na činjenicu da se vakuum sušenjem pjenaste paste rajčice pri temperaturi od $50{ }^{\circ} \mathrm{C}$ mogu proizvoditi visoko kvalitetni prahova od rajčice koji su kvalitativno slični prahovima dobiveni liofilizacijom, ali u kraćem vremenu i uz manje troškove procesa.

Proces vakuum sušenja pogodan je za proizvodnju prirodnih antioksidansa, fitonutrijenata ili dodataka prehrani.

Shonte i suradnici (2020) konvencionalno su sušili su koprivu pri $70{ }^{\circ} \mathrm{C}$ tijekom 15 sati i liofilizacijom pri $-40{ }^{\circ} \mathrm{C}$ tijekom 5 dana. Utvrdili su da sadržaj vitamina $C, \beta$-karotena i ukupnih fenolnih spojeva značajno $(\mathrm{p}<0.01)$ ovisi o primijenjenom procesu sušenja. Sadržaj vitamina C i $\beta$-karotena je bio veći u uzorcima koprive sušenih liofilizacijom. U ovom radu, pri sušenju koprive liofilizacijom gubitak vitamina $\mathrm{C}$ je iznosio 12 $\%$, a konvencionalnim sušenjem pri $70{ }^{\circ} \mathrm{C}$ je taj gubitak iznosio $22 \%$. Prema Shiltonu (2003) gubitak vitamina $\mathrm{C}$ u prehrambenim sirovinama uglavnom iznosi $10 \%$ to $50 \%$ ovisno o temperaturi sušenja. Prethodna istraživanja su također potvrdila da se liofilizacijom biljnih sirovina postiže bolje očuvanje vitamina Ci $\beta$-karotena (Abascal i sur., 2005; Gupta i sur., 2013). Najveći udio ukupnih fenola imala je konvencionalno sušena kopriva pri temperaturi od $70{ }^{\circ} \mathrm{C}$. Prema autorima, pri toj temperaturi dolazi do povećanja topljivosti fenolnih spojeva u otapalu, povećanja koeficijenta difuzije kao i pucanja glikozidne veze i nastajanja aglikona koji bolje reagiraju s Folin-Ciocalteu reagensom što rezultira većom vrijednosti ukupnih fenola. U istraživanju Nemzer i suradnika (2018) ispitan je utjecaj sušenja jagoda, borovnica i brusnica u struji vrućeg zraka (pri $70{ }^{\circ} \mathrm{C}$ ) i liofilizacijom pri $-64^{\circ} \mathrm{C}$ i tlaku od $6,67 \mathrm{~Pa}$ te je veći udio vitamina $\mathrm{C}$, antocijana $\mathrm{i}$ fenolnih spojeva određen $\mathrm{u}$ liofiliziranom voću. Najveći udio fenolnih spojeva određen je u liofiliziranim jagodama u odnosu na jagode sušene u struji vrućeg zraka pri $70^{\circ} \mathrm{C}$, mikrovalnim vakuum sušenjem pri snagama od 240, 360 i $480 \mathrm{~W}$ i konvencionalnim vakuum sušenjem pri $50{ }^{\circ} \mathrm{C}$ i $100 \mathrm{~Pa}$, (Wojdylo i sur 2009). Michalczyk i suradnici (2008) su proučavali utjecaj sušenja u struji vrućeg zraka pri $40{ }^{\circ} \mathrm{C}$ i liofilizacije pri $-23{ }^{\circ} \mathrm{C}$ na kvalitetu i antioksidacijsku aktivnost malina, jagoda i borovnica te je također utvrđena bolja kvaliteta i veća antioksidacijska aktivnost liofiliziranog voća.

\section{Mikrovalno vakuum sušenje}

Zadnjih godina sve više se istražuje mikrovalno vakuum sušenje kao potencijalna metoda za proizvodnju visoko kvalitetnih dehidriranih proizvoda. Mikrovalno vakuum sušenje kombinira prednosti vakuum i mikrovalnog sušenja te se postiže veća energetska učinkovitost, ali i kvaliteta sušenog proizvoda.

Mikrovalovi pokrivaju polje elektromagnetskog spektra u rasponu od $300 \mathrm{MHz}$ do $300 \mathrm{GHz}$, što odgovara valnoj duljini od $1 \mathrm{~mm}$ do $1 \mathrm{~m}$ (između radio valova $i$ infracrvenog zračenja). Materijal u mikrovalnim 
vakuum sušarama izlaže se zračenju frekvencije od $2450 \mathrm{MHz}$, što odgovara valnoj duljini od 12,2 cm u vakuumu (Drouzas i Schuber, 1996). Pri mikrovalnom vakuum sušenju prehrambenih sirovina skraćuje se vrijeme sušenja od 25 do $90 \%$ (Ruiz Diaz i sur., 2003), a brzina sušenja se povećava 4 do 8 puta (Maskan, 2001) u usporedbi s konvekcijskim sušenjem. Općenito, temperatura sušenja i snaga mikrovalova su glavni čimbenici koji utječu na učinkovitost ovog procesa sušenja i kvalitetu konačnog proizvoda. Proces mikrovalnog vakuum sušenja je 20 do 30 puta brži u odnosu na sušenje zamrzavanjem u vakuumu. S ekonomskog stajališta, mikrovalno vakuum sušenje se pozicioniralo između sušenja raspršivanjem i sušenja zamrzavanjem u vakuumu. Kapitalne investicije u opremu za mikrovalno vakuum sušenje iznose $60 \%$ troškova opreme za liofilizaciju, a operativni troškovi su 3 do 4 puta manji. Također, mikrovalnim sušenjem može se postići poboljšanje kvalitete proizvoda koje se očituje kao bolje zadržavanje arome (Feng i sur., 1999) i boje (Soysal, 2004). Međutim, zbog razlika u svojstvima i obliku materijala koji se suši, može doći do nejednolikog zagrijavanja tijekom sušenja u mikrovalnoj sušari te posljedično do nepoželjne promjene senzorskih svojstava.

Mikrovalna vakuum sušara sastoji se od komore, vakuum sustava, kontrolnog sustava i izvora mikrovalova (magnetrona) (Slika 5).
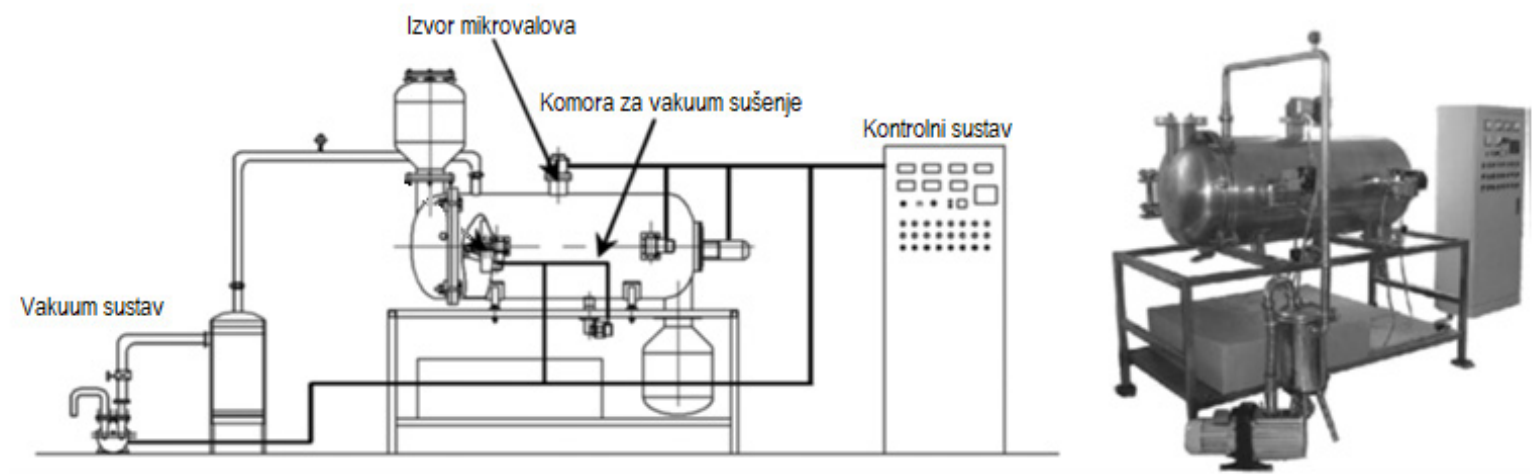

Slika 5. Mikrovalna vakuum sušara (Han i sur., 2010)

Figure 5. Microwave vacuum dryer (Han et al., 2010)

Sunjka i suradnici (2004) ispitivali su utjecaj mikrovalnog vakuum sušenja (1.25 W/g uzorka; 3,4 kPa) i mikrovalnog sušenja u struji vrućeg zraka $\left(1.25 \mathrm{~W} / \mathrm{g}\right.$ uzorka; $\left.62{ }^{\circ} \mathrm{C}\right)$ na svojstva brusnice, ali i potrošnju energije. Senzorska svojstva (boja, okus, tekstura, izgled) osušenih brusnica ocijenio je senzorski panel. Panel je bolje ocijenio brusnice osušene pomoću mikrovalova u struji vrućeg zraka. Boja i tekstura određeni su i instrumentalno. Nisu utvrđene značajne razlike u instrumentalno određenim svojstvima u odnosu na način mikrovalnog sušenja, ali su utvrdili da je mikrovalnovakuum sušenje energetski učinkovitije od mikrovalno konvekcijskog sušenja. Figiel (2009) je istraživao utjecaj konvekcijskog i mikrovalnog vakuum sušenja pri tri različite snage mikrovalova $(240,480$ i $720 \mathrm{~W})$ na kinetiku sušenja i aromu češnjaka. Utvrdio je da je udio hlapljivih ulja veći u uzorcima češnjaka nakon mikrovalnog vakuum sušenja te da se s povećanjem snage mikrovalova povećava brzina sušenja odnosno skraćuje vrijeme sušenja.

Potrošnja energije i vrijeme sušenja prehrambenih sirovina pri mikrovalnom vakuum sušenju i sušenju u struji vrućeg zraka prikazane su u Tablici 5.

Tablica 5. Potrošnja energije i vrijeme sušenja prehrambenih sirovina pri mikrovalnom vakuum sušenju i sušenju u struji vrućeg zraka

Table 5. Energy consumption and drying time during microwave-vacuum drying and hot air drying of food

\begin{tabular}{|c|c|c|c|c|c|}
\hline Sirovina & $\begin{array}{c}\text { MWVS } \\
\text { Vrijeme sušenja (h) }\end{array}$ & $\begin{array}{c}\text { HAD } \\
\text { Vrijeme sušenja (h) }\end{array}$ & $\begin{array}{c}\text { MWVS } \\
\text { Potrošnja energije } \\
\left(\mathrm{kWhkg}^{-1}\right)\end{array}$ & $\begin{array}{c}\text { HAD } \\
\text { Potrošnja energije } \\
\left(\mathrm{kWhkg}^{-1}\right)\end{array}$ & Literaturni navod \\
\hline bamija & 0,25 & 8,2 & 4 & 49 & Jiang i sur., 2017 \\
\hline rajčica & 0,58 & 72 & 48 & 231 & Orikasa i sur., 2018 \\
\hline gljive & 0,60 & 3,55 & 6 & 50 & Motevali i sur., 2011 \\
\hline ružmarin & 0,6 & 5,5 & 10 & 29 & Ali i sur., 2020 \\
\hline rajčica & 0,81 & 14,75 & 31 & 111 & Durance i Wang, 2002 \\
\hline
\end{tabular}

MWVS- mikrovalno vakuum sušenje

HAD- sušenje u struji vrućeg zraka

Mikrovalnim vakuum sušenjem najčešće se suše sirovine iz kojih se dobivaju prehrambeni prahovi i proizvodi porozne strukture. Porozna struktura proizvoda dobivenih mikrovalnim vakuum sušenjem omogućava kraće vrijeme rehidratacije, ali i bolju rehidrataciju (Durance i Wang, 2002; Drouzas i Schubert, 1996; Setiady i sur., 2009). Therdthai i Northongkom (2011) su sušili kineski đumbir u struji vrućeg zraka i mikrovalovima u vakuumu. Koeficijent difuzije vlage pri sušenju vrućim zrakom pri temperaturama 60 i $70{ }^{\circ} \mathrm{C}$ je bio $0,207310^{-10}$ i $0,410610^{-10} \mathrm{~m}^{2} / \mathrm{s}$ dok je koeficijent difuzije vlage sušenjem mikrovalovima snage $2880 \mathrm{~W}$ i $3360 \mathrm{~W}$ i vakuumom od $13,3 \mathrm{kPa}$ bio veći, i to $5,791010^{-10}$ i $6,876710^{-10} \mathrm{~m}^{2} / \mathrm{s}$, tj. mikrovalno vakuum 
sušenje je bilo do 90 \% kraće u usporedbi sa sušenjem u struji vrućeg zraka. Također su uočili znatno poboljšanu sposobnost rehidratacije uzoraka sušenih mikrovalovima u vakuumu za razliku od uzoraka sušenih u struji vrućeg zraka. Giri i Prasad (2007) su istraživali utjecaj sušenja u struji vrućeg zraka $\left(50,60\right.$ i $\left.70{ }^{\circ} \mathrm{C}\right)$ i mikrovalnog vakuum sušenja pri snazi mikrovalova 115 do $285 \mathrm{~W}$ i tlakovima od 10 do 20 $\mathrm{kPa}$ na kinetiku sušenja, poroznost i rehidratacijska svojstva gljiva. Utvrdili su da je mikrovalno vakuum sušenje bilo $90 \%$ kraće u odnosu na sušenje u struji vrućeg zraka kako bi se postigao udio vlage od $6 \%$. Poroznost i rehidratacijska svojstva gljiva su bili bolji kod onih osušenih mikrovalnim vakuum sušenjem koje je provedeno pri nižim tlakovima i višim snagama mikrovalova što je u skladu s rezultatima Drouzas i Schuberta (1996) i Durance i Wang-a (2002).

\section{Zaključci}

Konvencionalno vakuum sušenje, mikrovalno vakuum sušenje i sušenje zamrzavanjem u vakuumu su najpoznatiji procesi sušenja u vakuumu. Konvencionalno sušenje $u$ vakuumu je najjeftiniji proces sušenja $u$ uvjetima sniženog tlaka kojim se dobiva proizvod bolje kvalitete u odnosu na konvencionalno sušenje vrućim zrakom. Mikrovalno vakuum sušenje ima najkraće vrijeme sušenja i energetski je učinkovitije u odnosu na konvencionalno sušenje vrućim zrakom. Liofilizacija odnosno sušenje zamrzavanjem u vakuumu daje proizvod najboljih nutritivnih i senzorskih svojstava, ali je vrlo skup proces. Svaki od navedenih procesa sušenja u vakuumu ima određene prednosti i nedostatke, a odabir ovisi o vrsti sirovine i ciljanoj kvaliteti proizvoda. Na temelju rezultata istraživanja sušenjem u vakuumu u odnosu na sušenje pri atmosferskom tlaku, osušeni proizvodi imaju bolje očuvanu teksturu, boju i okus proizvoda kao i veći udio biološki aktivnih spojeva. Navedene sačuvane vrijednosti proizvoda kao i konstantan porast potražnje za minimalno industrijski prerađenom namirnicom, ekonomski i energetski opravdavaju proces vakuum sušenja te on postaje sinonim za kvalitetno sušenje hrane.

\section{Zahvala}

Ovaj rad je financirala Hrvatska zaklada za znanost projektom „Hibridno sušenje i valorizacija biljnog prehrambenog otpada i nusproizvoda“ (IP2019-04-9750) - HYDRYBY.

\section{Literatura}

Abascal K., Ganora L., Yarnell E. (2005) The effect of freeze-drying and its implications for botanical medicine: a review. Phytotherapy Research, 19 (8) 655-660.

Akar G., Mazi I. B. (2019) Color change, ascorbic acid degradation kinetics, and rehydration behavior of kiwifruit as affected by different drying methods. Journal of Food Processing and Engineering, 42 (3) 1-16.

Aksoy A., Karasu S., Akcicek A., Kayacan S. (2019) Effects of Different Drying Methods on Drying Kinetics, Microstructure, Color, and the Rehydration Ratio of Minced Meat. Foods, 8 (216) 1-14.

Ali A., Oon C. C., Chua B. L., Figiel A., Chong C.H., Wojdylo A., Turkiewicz I.P., Szumny A., Lyczko J. (2020) Volatile and polyphenol composition, anti-oxidant, anti-diabetic and anti-aging properties, and drying kinetics as affected by convective and hybrid vacuum microwave drying of Rosmarinus officinalis L. Industrial Crops and Products, 151

Anonymus 1, Promas Engg (2013) Vacuum tray dryer. Dostupno na: http://promasengineers.blogspot.com/2013/09/vtdarticle2013.html. Pristupljeno: 07.09.2020.

Anonymus 2, Hegatec engineering. Vacuum belt dryer. Dostupno na: http://www.hegatec.com/technologies/vacuumbeltdryer.html Pristupljeno: 16.3.2020.

Anonymus 3,Vacuum dryers. Dostupno na: https://bachiller.com/en/vacuum-dryers/Pristupljeno: 16.8.2020

Anonymus 4, Lyotech.Dostupno na: https://coolvacuum.es/en/food-industry-freezedrying/lyotech/ Pristupljeno: 16.8.2020.

Arevalo-Pinedo A., Murr F. E. X. (2006) Kinetics of vacuum drying of pumpkin (Cucurbita maxima): Modeling with shrinkage. Journal of Food Engineering, 76 562-567.

Arevalo-Pinedo A., Murr F. E. X., Arevalo Z. D. S., Giraldo-Zuniga A. D. (2010) Modeling with Shrinkage during the Vacuum Drying of Carrot (Daucus Carota). Journal of Food Processing and Preservation, 34 611-621.

Balzarini M.F., Reinheimer M. A., Ciappini M. C. Scenna N. J. (2018) Comparative study of hot air and vacuum drying on the drying kinetics and physicochemical properties of chicory roots. Journal of Food Science and Technology, 55 (10) 4067-4078.

Berk Z. (2009). Freeze drying (lyophilization) and freeze concentration. Food process engineering and technology. Elsevier, New York.

da Silva V., Lins de Melo E., Batista de Medeiros L., Pimenta Barros R.A., Azoubel Z.M., Moreira. P. (2018) Influence of ultrasound and vacuum assisted drying on papaya quality parameters, LWT-Food Science and Technology, 97 317-322.

Drouzas A.E., Schubert H. (1996) Microwave application in vacuum drying of fruits. Journal of Food Engineering, $28203-209$.

Durance T,D., Wang J.H. (2002) Energy consumption, density, and rehydration rate of vacuum microwave- and hot-air convection- dehydrated tomatoes. Journal of Food Science, 67 (6) 2212-2216.

Feng H., Tang J., Mattinson D.S., Fellman J.K. (1999) Microwave and spouted bed drying characteristics of microwave-vacuum and convective hotair dried mushrooms. Journal of Food Engineering, 78 512-521.

Figiel A. (2009) Drying kinetics and quality of vacuum-microwave dehydrated garlic cloves and slices. Journal of Food Engineering, 94 98-104.

Giri S. K., Prasad S. (2007) Drying kinetics and rehydration characteristics of microwave-vacuum and convective hot-air dried mushrooms. Journal of Food Engineering 78: 512-521.

Gümüşay O.A., Borazan A.A., Ercal N., Demirkol O. (2014) Drying effects on the antioxidant properties of tomatoes and ginger, Food Chemistry, 173 156-162.

Gupta S., Gowri B.S., Lakshmi A. J., Prakash J. (2013) Retention of nutrients in green leafy vegetables on dehydration. Journal of Food Science and Technology, 50 (5) 918-925.

Han, Q.H., Yin, L.J., Li, S.J., Yang, B.N., Ma, J.W. (2010) Optimization of Process Parameters for Microwave Vacuum Drying of Apple Slices Using Response Surface Method. Drying Technology, 28 523-532.

Hua T.C., Liu B.L., Zhang H. (2018) Requirement of ice sublimation to freeze-drying system U: Freeze-Drying of Pharmaceutical and Food Products. Woodhead Publishing. Boca Raton, USA.

Jaya S., Das H. (2003) A vacuum drying model for mango pulp. Drying Technology, 21 1215-1234. 
Jena, S., Das H. (2007) Modelling for vacuum drying characteristics of coconut presscake. Journal of Food Engineering, $7092-99$.

Jian, N., Zhan, Z., Li, D., Li, C., Zhan, M., Li, C., Wan, D., Ni, L. (2017) Evaluation of freeze drying combined with microwave vacuum drying for functional okra snacks: Antioxidant properties, sensory quality, and energy consumption. LWT - Food Science and Technology, 82 $1216-226$.

Koretsk, M.D. (2004) Engineering and chemical thermodynamics. Wiley, Hoboken.

Koru, A. (2011) Effect of preliminary processing, method of drying and storage temperature on the level of antioxidants in kale (Brassica oleracea L. var. acephala) leaves. LWT-Food Science and Technology, 44 1711-1716.

Li, C., Grim, N., Lebovk, N., Vorobiev E. (2018) Effects of pulsed electric fields treatment on vacuum drying of potato tissue. LebensmittelWissenschaft und-Technologie / Food Science and Technology, 95, 289-294.

Madamba S., Liboon F. (2007) Optimization of the vacuum dehydration of celery (Apium Graveolens) using the response surface methodology. Drying Technology, 19 (3-4) 611-626.

Maskan M. (2001) Drying, shrinkage and rehydration characteristics of kiwifruits during hot air and microwave drying. Journal of Food Engineering, 48 177-182.

Michalcayk M., Macura R., Matuszak I. (2009) The effect of air-drying, freeze-drying and storage on the quality and antioxidant activity of some selected berries. Journal of Food Processing and Preservation, 33 11-21.

Mitra J., Shrivastava S.L., Rao P.S. (2011) Process optimisation of vacuum drying of onion slices. Czech Journal of Food Science, 29 586-594.

Motevali A., Minaei S., Hadi M., Amirnejat K. H. (2011) Comparison of energy consumption and specific energy requirements of different methods for drying mushroom slices. Energy, 36 (11) 6433-644.

Nemzer B., Vargas L., Xia X.Y., Sintara M., Feng H. (2018) Phytochemical and physical properties of blueberries, tart cherries, strawberries, and cranberries as affected by different drying methods. Food Chemistry, 262 242-250.

Orikasa T., Koide S., Okamoto S., Imaizumi T., Muramatsu Y.,Takeda J., Shiina T., Tagawa A. (2014) Impacts of hot air and vacuum drying on the quality attributes of kiwifruit slices. Journal of Food Engineering. 125 51-58.

Orikasa T., Koide S., Sugawara H., Yoshida M., Kato K., Matsushima M., Okada M., Watanabe T., Ando Y., Shiina T., Tagawa A. (2018) Applicability of vacuum-microwave drying for tomato fruit based on evaluations of energy cost, color, functional components, and sensory qualities. Journal of Food Processing and Preservation, 42 1-12.

Tekin Z. H., Baslar M., Karasu S., Kilicli M. (2017) Dehydration of green beans using ultrasound-assisted vacuum drying as a novel technique: drying kinetics and quality parameters. Journal of Food Processing and Preservation, 416 1-10.

Ratti C. (2001) Hot air and freeze-drying of high-value foods: a review. Journal of Food Engineering, 49 (4) 311-319.

Reis F. R (2014) Vacuum Drying for Extending Food Shelf-Life, Springer, str. 19-29.

Ruız Diaz G., Martınez-Monzo J., Chiralt P.F.A. (2003) Modelling of dehydration-rehydration of orange slices in combined microwave/ air drying. Innovative Food Science and Emerging Technology, 4203-209.

Setiady D., Tang J., Younce F., Swanson B.A., Rasco B.A., Clary C.D. (2009) Porosity, color, texture and microscopic structure of russet potatoes dried using microwave vacuum, heated air, and freeze drying. ASABE Applied Engineering in Agriculture, 25 (5) 719-724.

Shonte T.T., Duodu K.G., de Kock H.L. (2020) Effect of drying methods on chemical composition and antioxidant activity of underutilized stinging nettle leaves. Heliyon, 65 1-10.

Shilton N. (2003) Drying: Chemical changes. B. Caballero, L. Trugo, P. Finglas (Ured.), U: Encyclopaedia of Food and Health (Second), Elsevier Science Ltd, Amsterdam, Netherlands. str. 1947-1950.

Soysal Y. (2004) Microwave drying characteristics of parsley. Biosystems Engineering, 89 167-173.

Sramek M., Schweiggert R. M., van Kampen A., Carle R., Kohlus R. (2015) Preparation of High-Grade Powders from Tomato Paste Using a Vacuum Foam Drying Method. Journal of Food Science, 80 (8) 1755-1762.

Sunjka P. S., Rennie T. J., Beaudry C., Raghavan G. S. V. (2004) Microwave-convective and microwave-vacuum drying of cranberries: A comparative study. Drying Technology, 22 (5) 1217-1231.

Šic Žlabur J, Colnar D., Voća S., Lorenzo J.M., Munekata P.E.S, Barba .FJ., Dobričević N. Galić A., Dujmić F., Pliestić S., Brnčić M.(2019) Effect of ultrasound pre-treatment and drying method on specialized metabolites of honeyberry fruits (Lonicera caerulea var. kamtschatica). Ultrasonics sonochemistry, 56 372-377.

Šumić Z., Tepić A., Vidović S., Vakula A., Vladić J., Pavlić B. (2017) Process optimization of chanterelle (Cantharellus cibarius) mushrooms vacuum drying. Journal of Food Processing and Preservation, 41 (2) 1-12.

Therdthai N., Northongkom H. (2011) Characterization of hot air drying and microwave vacuum drying of fingerroot (Boesenbergia pandurata). International Journal of Food Science \& Technology, 46 (3) 601-607.

van't Land C. M. (2011a) Continuous Moisture-Measurement Methods, Dryer Process Control, and Energy Recovery. U: Drying in the Process Industry, John Wiley \& Sons, Inc. str. 313-337.

van't Land C. M. (2011b) Convective Drying. U: Drying in the Process Industry, John Wiley \& Sons, Inc. str. 41-66.

van't Land C. M. (2011c) Vacuum Drying. U: Drying in the Process Industry, John Wiley \& Sons, Inc. str. 217-249

Yan H., Kerr W.L. (2012) Total phenolics content, anthocyanins, and dietary fiber content of apple pomace powders produced by vacuum-belt drying. Journal of Science and Food in Agriculture, 936 1499-504.

Zambrano M. V., Dutta B., Mercer D. G., MacLeana H. L.,Touchie M. F. (2019) Assessment of moisture content measurement methods of dried food products in small-scale operations in developing countries: A review. Trends in Food Science \& Technology, 88 484-496.

Wojdyło A., Figiel A., Oszmiański J. (2009) Effect of drying methods with the application

of vacuum microwaves on the bioactive compounds, color, and antioxidant activity of strawberry fruits. Journal of Agricultural and Food Chemistry, $57,1337-1343$.

Wu L., Orikasa T., Ogawa Y. (2007) Vacuum drying characteristics of eggplants. Journal of Food Engineering, $83422-429$. 